\title{
"South African FX Earning Model: - A Replica of Growth for Mining Industry of Jharkhand"
}

\author{
Devesh Kumar* \& Dr. M. K. Singh** \\ *Research Scholar, Department of Commerce \& Management, Vinoba Bhave University, Hazaribag, \\ Jharkhand-825301; \\ ** President, Indian Commerce Association; Head \& Dean, Department of Commerce \& Management, Vinoba \\ Bhave University, Hazaribag, Jharkhand-825301;
}

\begin{abstract}
Jharkhand state a part of the Indian Peninsular Shield is a stable cratonic block of the earth's crust. Jharkhand is known for its diversified geological set up. The state owns $29.61 \%$ of forest area and about $40 \%$ of total mineral resources of India. During 2012-13, the value of minerals produced in Jharkhand was US\$ 3 billion. The state had a 7.4 per cent share in the total value of minerals (excluding atomic and minor minerals) produced in India. Mining and quarrying sector contributed around 10.2 per cent to the state's GSDP and about 7.4 per cent of total value of mineral production in the country in 2012-13. In South Africa, mining sector is an important foreign exchange earner, with minerals accounting for a significant contribution to economic activity (18\% of GDP), job creation (around one million), exports and foreign exchange earnings (more than 50\%), attracts significant foreign savings (43\% of Johannesburg Stock Exchange), accounts for $13.2 \%$ of corporate tax receipts \& for $94 \%$ of electricity generation via coal power plants. In this paper, we explore the possibility of replicating the South African Model to the Mining Industry of Jharkhand, so that the said industry will be a single largest contributor of state GDP. If we are able to use the forex products extensively in this mineral-rich state, we will certainly lessen the gap of vertical inequality (rich and poor populations) and horizontal inequality (mineral-rich \& mineral-poor regions like Singhbhum and Plamu districts).
\end{abstract}

Keywords: Mineral resource, Foreign exchange, FX Products, GSDP, Vertical \& horizontal inequality

\section{Introduction}

Jharkhand state a part of the Indian Peninsular Shield is a stable cratonic block of the earth's crust. Jharkhand is known for its diversified geological set up which is blessed with the natural gift of immense mineral potential and other natural resources. The state owns about $40 \%$ of total mineral resources of India. It occupies $1^{\text {st }}$ position in coal reserve, $2^{\text {nd }}$ position in Iron ore reserve, 3 rd position in Copper ore reserve, $7^{\text {th }}$ position in Bauxite reserve and is the sole producer of prime coking coal. Some other important minerals like Limestone, Dolomite, Manganese, Mica etc. are available in huge quantity in the state.

The state had a 7.4 per cent share in the total value of minerals (excluding atomic and minor minerals) produced in India. At current prices, the Gross State Domestic Product (GSDP) of Jharkhand for 2013-14 was estimated to have been US\$ 31.4 billion and Mining \& quarrying sector contributed around 10.2 per cent to the state's GSDP. The value of minerals produced in Jharkhand in the same period was about US\$ 3 billion. Government of Jharkhand is earning a revenue of around Rs.5,000 cr. as royalty collection from this industry.

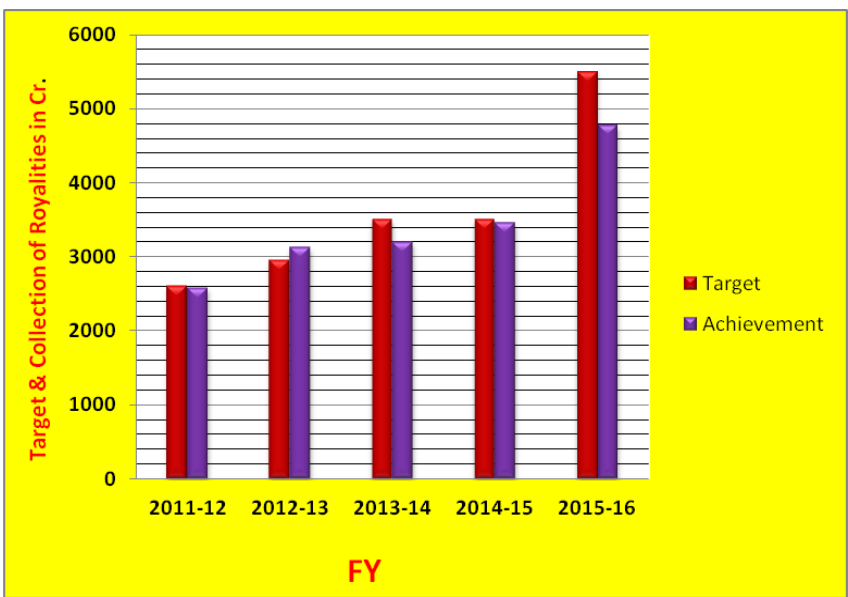

Fig. 1.1. Royalty collection Up to March'16 Directorate of Mines, Dept of Industries -Mines \& Geology, Govt. of Jharkhand 
In South Africa, mining sector is an important foreign exchange earner, with minerals accounting for a significant contribution to economic activity (18\% of GDP), job creation (around one million), exports and foreign exchange earnings (more than 50\%), attracts significant foreign savings (43\% of Johannesburg Stock Exchange), accounts for $13.2 \%$ of corporate tax receipts \& for $94 \%$ of electricity generation via coal power plants. Jharkhand can replicate the South African Model by using Mining Industry as single largest contributor of state GDP.

\section{FX Market of India}

The FX market plays an important role in the world economy and with the development of new technologies; currency markets have become accessible for all investors - individual, government or nongovernmental organizations (Chen, 2009). In India, foreign exchange was being conserved prior to 1990s. But Foreign Exchange Management Act 1999 changed the outlook of Indian foreign exchange market. It has facilitated external trade \& payment and promoted the orderly development \& maintenance of foreign exchange market. As a result, India as a foreign exchange starved country has been transformed into a $\$ 350$ billion+ club member (ref. fig.1.2).

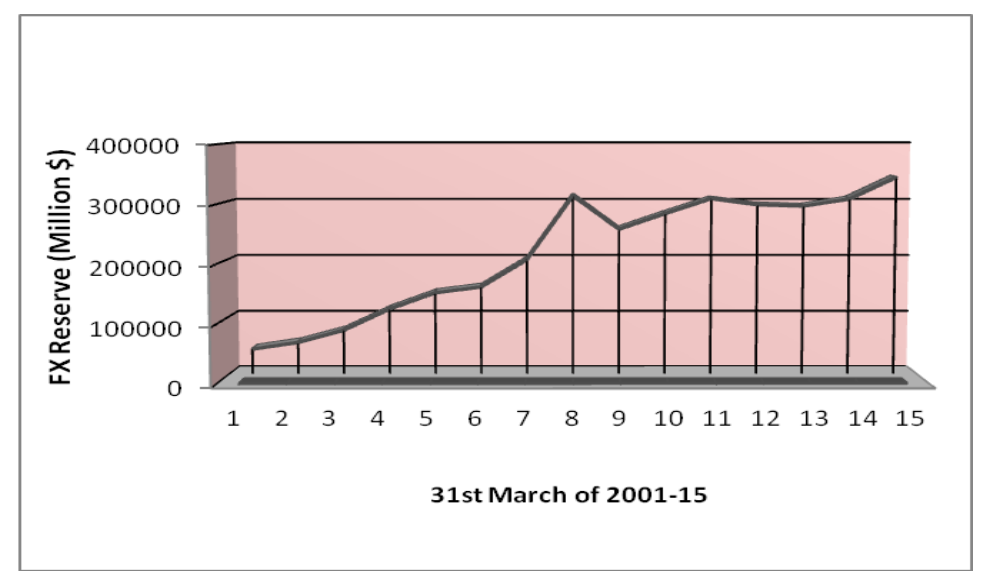

Fig.1.2 Forex Resrve of India in last 15 Yrs. (2001-15) https://data.gov.in/catalog/foreign-exchangereserves-year-wise

From time to time RBI intervenes in spot and forward market, if it feels exchange rate has deviated too much. One can see the purchase and sell data of RBI in fig. 1.3.

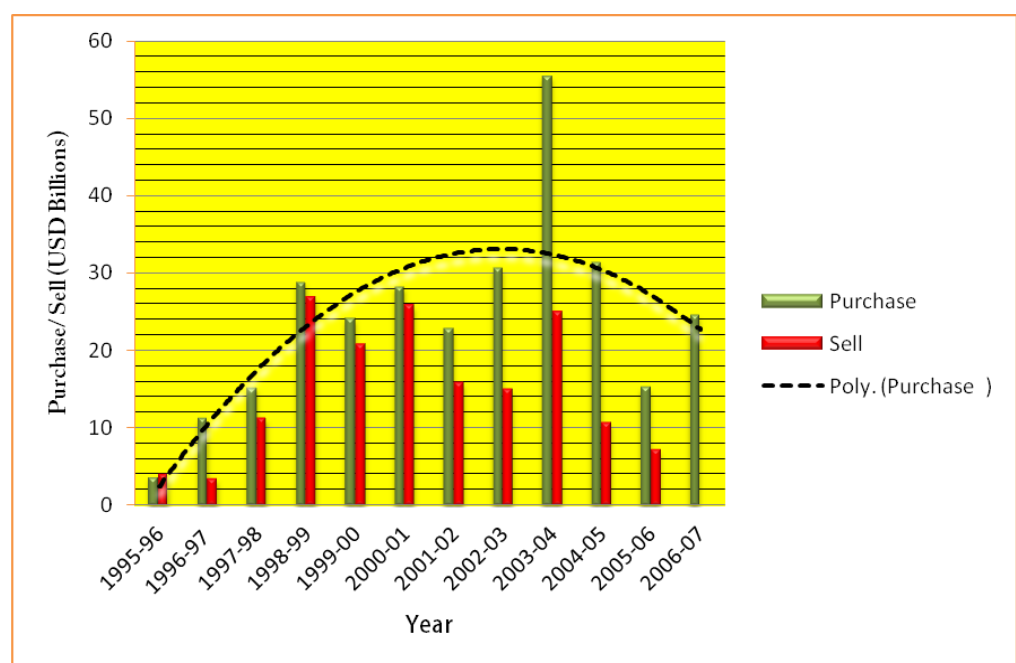

Fig.1.3 Purchase /Sell by RBI in a period of 10 yrs btw 1995-96 to 2006-07 (http://rbidocs.rbi.org.in/rdocs/publicationreport/pdfs/77577.pdf)

Market forces of demand and supply determine the value of any currency. Supply of currency is influenced by Central Banks. Performance of INR against four major currencies in last ten years can be seen in fig. 1.4. Yen has outperformed with an appreciating trend of about $68 \%$ in this period while the most used currency - USD got $2^{\text {nd }}$ spot with an appreciating trend of about $65.95 \%$. 


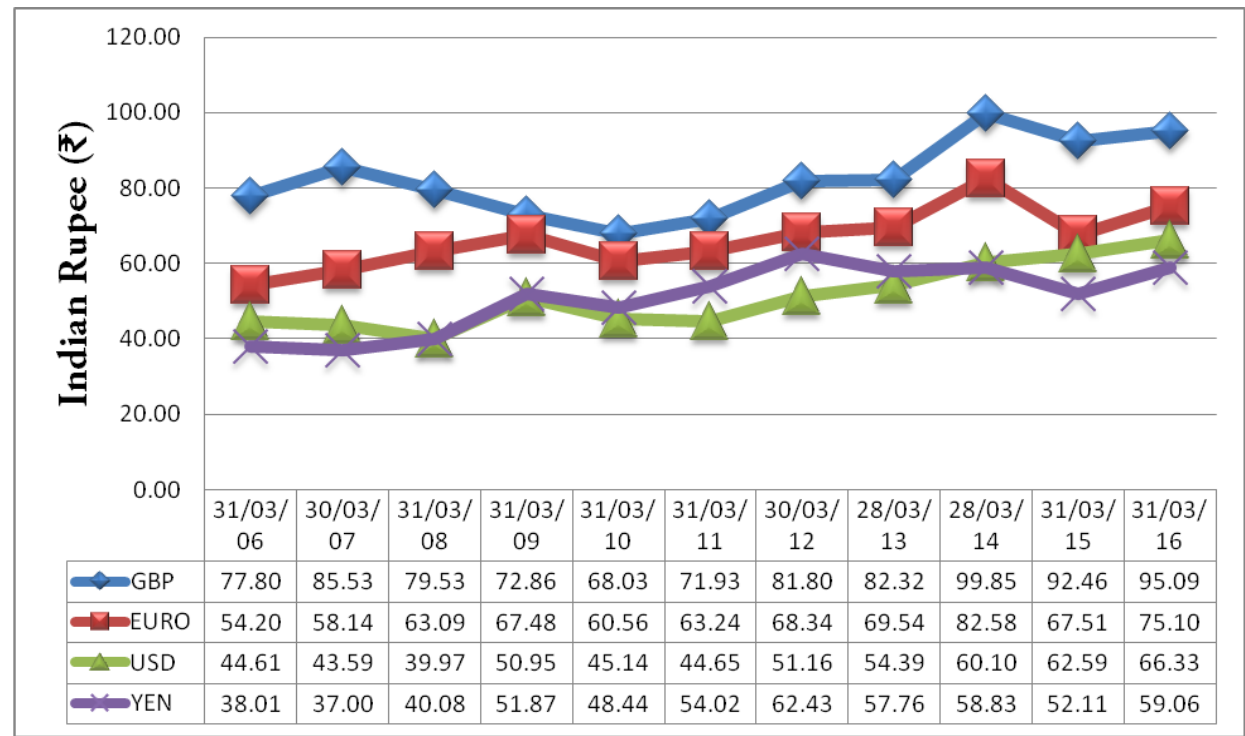

Fig. 1.4 Performance of Indian $\square$ against all major Currencies in last 10 Years (https://www.rbi.org.in/scripts/referenceratearchive.aspx)

\subsection{Objectives of the study}

The proposed study analyses the role of Forex in economy of a state. Further the impact of FX will be funnelled down to a particular Industry (mineral industry) of a particular state i.e, Jharkhand. Objectives of the study have been divided into the following segments:-

i. Trend analysis of the concerned market and its impact

ii. Detailed analysis of usage of FX products for maximizing profits and minimizing risk by mining Industry or Bankers

iii. Feasibility to replicate the South African Model to the Mining Industry of Jharkhand

\subsection{Scope of the study}

Though the impact of FOREX products in Jharkhand has been analyzed in this paper, it can be done in other states also.

\subsection{Research Methodology \\ Research Design:}

Qualitative research has been used extensively throughout the study. Some financial comparisons have been made based on production/revenue data provided by concerned Industries and opinion of engaged employees/investors. We tried to maximize the number of respondent to minimize the sample size bias as well as sample selection bias.

i) Primary Data:

Primary data is basically live data which we collected from respondents of different domains.

Sampling

$\Longrightarrow$ Convenient \& Non-Probability sample

Target groups Bankers, Corporate and Retail Customers

Sample size

of the study.

Number of respondent has been bifurcated according to objectives

Tools of data collection Structured Questionnaire, In-depth Interviews \& Delphi Technique

Details are in the following table:-

\begin{tabular}{|l|l|l|}
\hline S.No. & Objectives of the study & Tool/s of data collection \\
\hline I & $\begin{array}{l}\text { Trend analysis of the concerned market and its } \\
\text { impact }\end{array}$ & $\begin{array}{l}\text { Unstructured questionnaire, In-depth Interviews \& } \\
\text { references of secondary sources }\end{array}$ \\
\hline II & $\begin{array}{l}\text { Detailed analysis of usage of FX products for } \\
\text { maximizing profits and minimizing risk by } \\
\text { mining Industry or Bankers }\end{array}$ & $\begin{array}{l}\text { Structured Questionnaire, In-depth Interviews \& Delphi } \\
\text { Technique }\end{array}$ \\
\hline III & $\begin{array}{l}\text { Feasibility to replicate the South African Model } \\
\text { to the Mining Industry of Jharkhand }\end{array}$ & $\begin{array}{l}\text { Structured Questionnaire, In-depth Interviews \& Delphi } \\
\text { Technique }\end{array}$ \\
\hline
\end{tabular}


ii) Secondary Data

\begin{tabular}{|l|l|l|}
\hline S.No. & Objectives of the study & Source/s of secondary data \\
\hline I & $\begin{array}{l}\text { Trend analysis of the concerned market and its } \\
\text { impact }\end{array}$ & $\begin{array}{l}\text { RBI Master Circulars, Journals of various Institutes, } \\
\text { Newspaper articles, Data provided by different banks }\end{array}$ \\
\hline II & $\begin{array}{l}\text { Detailed analysis of usage of FX products for } \\
\text { maximizing profits and minimizing risk by } \\
\text { mining Industry or Bankers }\end{array}$ & $\begin{array}{l}\text { Newspaper articles, Data provided by different banks, } \\
\text { some previous research works and Primary data }\end{array}$ \\
\hline III & $\begin{array}{l}\text { Feasibility to replicate the South African Model } \\
\text { to the Mining Industry of Jharkhand }\end{array}$ & $\begin{array}{l}\text { Data provided by different banks, Annual reports of those } \\
\text { banks which are dealing in Forex in Jharkhand, some } \\
\text { previous research works and Primary data }\end{array}$ \\
\hline
\end{tabular}

\subsection{Data analysis and Interpretation}

We conducted three types of survey for:-

$i$. Inter \& Intra Bank \& Branch comparision [to know transactions in FX dealing]

ii. Inter Industry comparision [to know their competitive edge]

iii. Perception about the FX products [Corporate of Jharkhand \& India - specifically in Mining Industry]

(Inter \& Intra Bank \& Branch comparision)

\section{Data Analysis}

State Bank of India, Ranchi branch is the top scorer in the chart on accumulative basis. On customer service perspective, the branch is on lower side. However, the branch has topped in the operational efficiency and rate for FX transactions. Axis bank has lagged behind basically because of their rates for FX transactions. However they are more customer-friendly. The lowest performers are Indian Overseas Bank and Uco Bank of Giridih. Major reason for lagging behind is employees' reluctance. They are working in a public sector bank, so there is not as much pressure as in private banks. (ref. fig. 1.5)

\begin{tabular}{|c|c|c|c|c|c|c|c|c|c|}
\hline $\begin{array}{l}\text { Parameters of } \\
\text { comparision }\end{array}$ & $\begin{array}{l}\text { Sub-parameters of } \\
\text { comparision }\end{array}$ & $\begin{array}{l}\text { Axis } \\
\text { Bank, } \\
\text { Ranchi }\end{array}$ & \begin{tabular}{|l|} 
Axis \\
Bank, \\
Jamshedp \\
ur
\end{tabular} & \begin{tabular}{|l} 
Indian \\
Overseas \\
Bank, \\
Giridih \\
\end{tabular} & $\begin{array}{l}\text { Uco Bank, } \\
\text { Giridih }\end{array}$ & $\begin{array}{l}\text { IDBI } \\
\text { Bank, } \\
\text { Ranchi }\end{array}$ & \begin{tabular}{|l} 
Kotak \\
Mahindra \\
Bank , \\
Ranchi \\
\end{tabular} & $\begin{array}{l}\text { SBI Bank, } \\
\text { Ranchi }\end{array}$ & $\begin{array}{l}\text { SBI Bank, } \\
\text { Jamshedp } \\
\text { ur }\end{array}$ \\
\hline \multirow[t]{6}{*}{$\begin{array}{l}\text { Environment of the } \\
\text { Bank /Branch }\end{array}$} & Working environment & 4 & 4 & 3 & 3 & 4 & 4 & 4 & 4 \\
\hline & Product knowledge of Officials & 3 & 4 & 3 & 4 & 4 & 3 & 4 & 4 \\
\hline & Transparency in Operation & 4 & 4 & 3 & 3 & 4 & 4 & 4 & 4 \\
\hline & Operational knowledge & 3 & 3 & 3 & 4 & 3 & 3 & 4 & 4 \\
\hline & Technological advancement & 4 & 4 & 3 & 3 & 4 & 4 & 4 & 4 \\
\hline & Documentation Process & 4 & 3 & 3 & 3 & 3 & 4 & 3 & 3 \\
\hline \multirow[t]{3}{*}{ HR } & Attitude of Employees & 4 & 3 & 3 & 3 & 3 & 4 & 4 & 3 \\
\hline & Co-ordination between Staffs & 4 & 3 & 2 & 3 & 3 & 4 & 3 & 4 \\
\hline & Work culture & 3 & 3 & 3 & 3 & 3 & 3 & 3 & 3 \\
\hline \multirow[t]{5}{*}{ Customer's View } & $\begin{array}{l}\text { Average Operational time for } 1 \\
\text { customer }\end{array}$ & 3 & 3 & 2 & 3 & 3 & 3 & 3 & 3 \\
\hline & Customer's Response & 4 & 4 & 2 & 3 & 4 & 4 & 4 & 3 \\
\hline & Facilities for Customers & 3 & 3 & 2 & 2 & 3 & 4 & 3 & 4 \\
\hline & Grievance Redressal & 3 & 3 & 3 & 2 & 3 & 3 & 3 & 3 \\
\hline & Charges & 2 & 2 & 4 & 4 & 3 & 2 & 5 & 5 \\
\hline \multirow[t]{3}{*}{ Superior's View } & $\begin{array}{l}\text { Behaviour of Superior } \\
\text { authorities to Subordinates }\end{array}$ & 3 & 3 & 3 & 3 & 3 & 3 & 3 & 3 \\
\hline & Marketing Strategies & 3 & 3 & 1 & 1 & 3 & 3 & 3 & 3 \\
\hline & Job Enrichment & 3 & 3 & 1 & 1 & 3 & 3 & 4 & 3 \\
\hline \multirow[t]{3}{*}{ Sub-ordinate's View } & Assistance from Superiors & 4 & 4 & 2 & 3 & 4 & 4 & 3 & 4 \\
\hline & Job Satisfaction & 3 & 3 & 3 & 3 & 3 & 3 & 4 & 3 \\
\hline & Proper Infrastructure & 4 & 4 & 2 & 3 & 4 & 4 & 4 & 4 \\
\hline Total Points for Rating & & 68 & 66 & 51 & 57 & 67 & 69 & 72 & 71 \\
\hline
\end{tabular}

Fig. 1.5 Inter \& Intra Bank Branch comparision (Inter Industry comparision)

State bank of India again topped the list due to its vast network and global recognition. State bank of India and Axis bank were considered as more secure banks in FX transactions. Norms \& regulations wee almost same for all banks except Indian Overseas Bank which was more regualtions-oriented. Charges \& commissions were the best in State bank of India, while worst in Axis bank. 


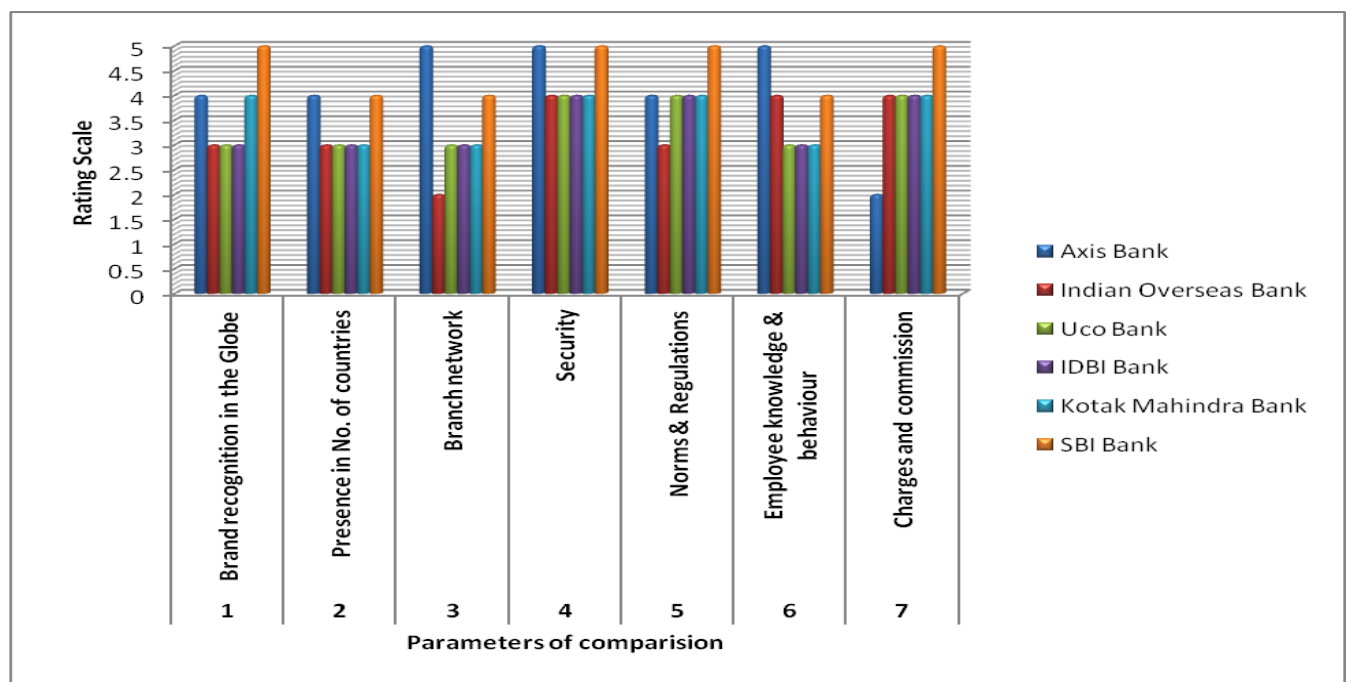

Fig. 1.6 Inter Industry comparision

(Perception about the FX products)

a. Normally a person above than 40 years are preferring to play in this market as shown in the below graph. The data suggests that a strong link between their income level and risk taking abilities.

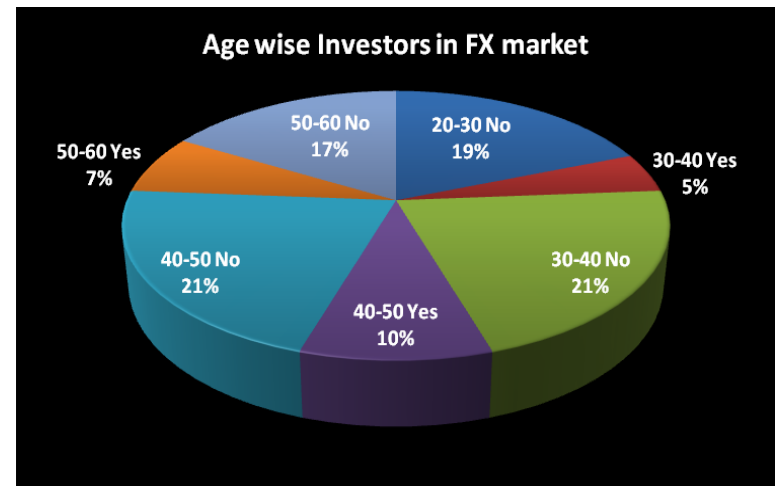

Fig. 1.7 Age wise Investors in FX market

b. Frequency of investment in FX market :- $49 \%$ of respondents are not doing any investment in the said market. Only $14 \%$ respondents are doing investments in this market. But majority of the investors were preffering yearly $(6 \%)$ or half yearly $(5 \%)$. They were cautioys about the volatility of the market, so they were not investing in the short term funds. (ref. Fig. 1.8)

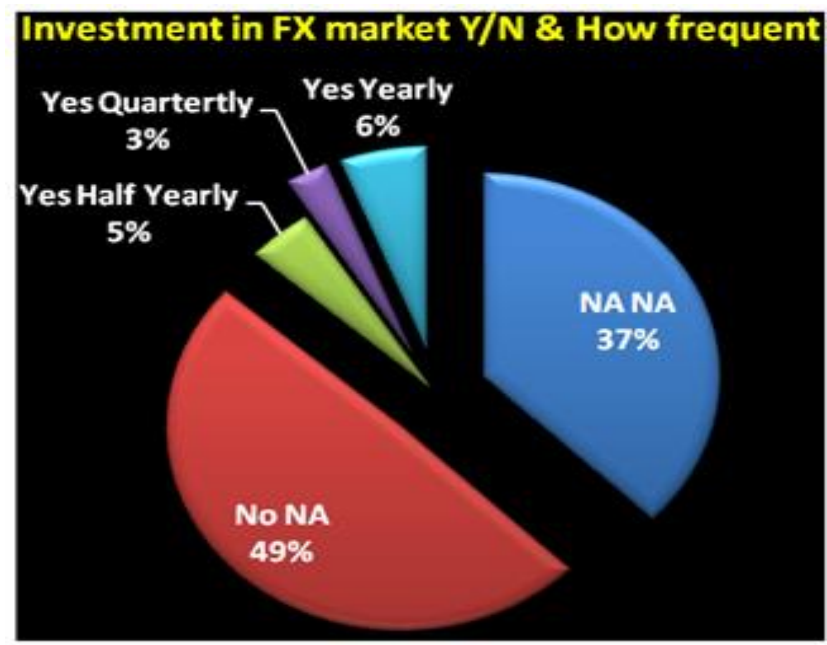

Fig. 1.8 Invesstment pattern in FX market 
c. Fear of risks associated with the FX market :- Yes investors were afraid of negative return of this market. $10 \%$ respondents were in favour of its very high risk nature of investment who are investing in the market and $12 \%$ respondents were in favour of its very high risk nature of investment who are not investing in the market. (ref. Fig. 1.9)

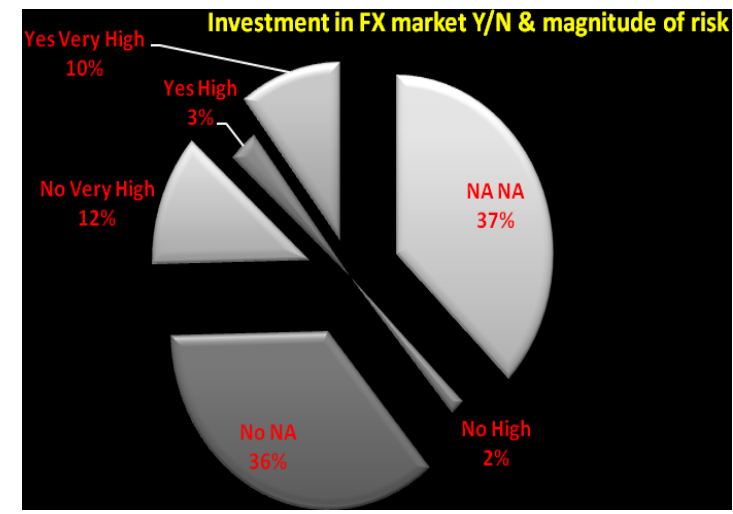

Fig. 1.9 Invesstment pattern in FX market as per magnitude of risk

d. Types of FX dealings performed :- Mostly respondents (27\%) were receiving money from abroad, so they were not much aware about this market. Only $9 \%$ of respondents were doing investments in the market (ref. fig. 2.0).

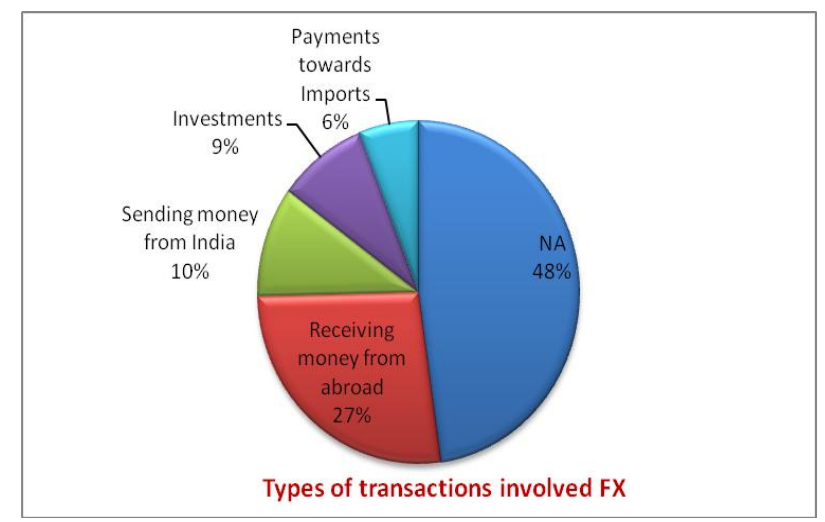

Fig. 2.0 Types of transactions involving FX market

If we see the regional variation of the transactions, we found that in investments in this market, Gujrat topped the list; in money receiving from outside Jharkhand topped the list; in imports, Andhra Pradesh, Delhi and Gujrat were on the same wavelength and in money sending outside of the country, almost every state was showing some presence. (ref. Fig.2.1).

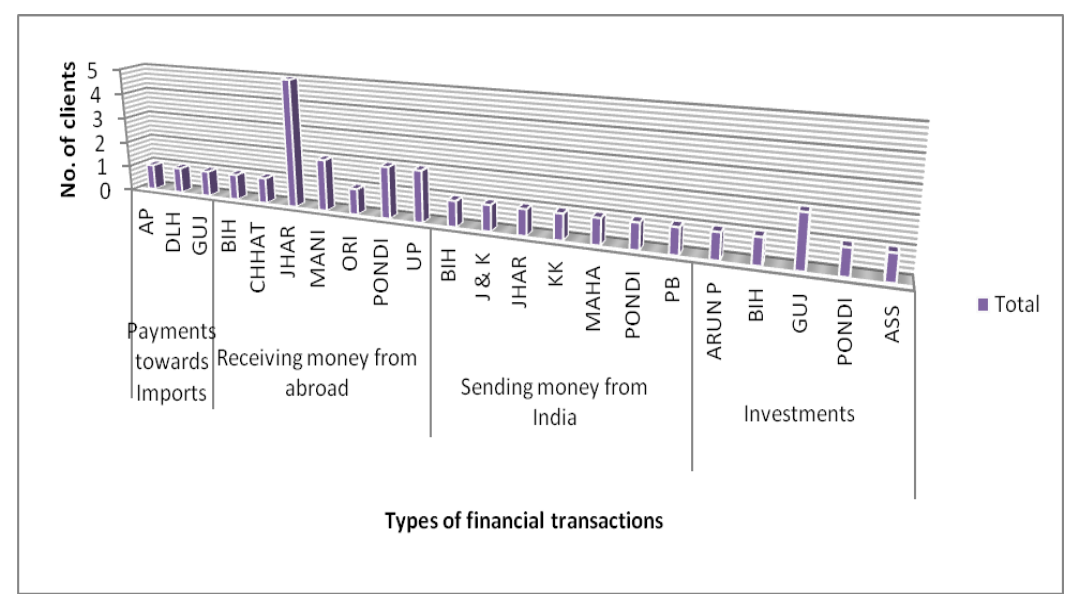

Fig. 2.1 Types of financial transactions involving FX market 
e. Regionalisation of FX market:- We oserved the regionalisation of FX market. States with good SGDP and economy are inclined towards this market, while states which economy is bad in shape are lagging behind in the chart of this market (ref.Fig. 2.2).

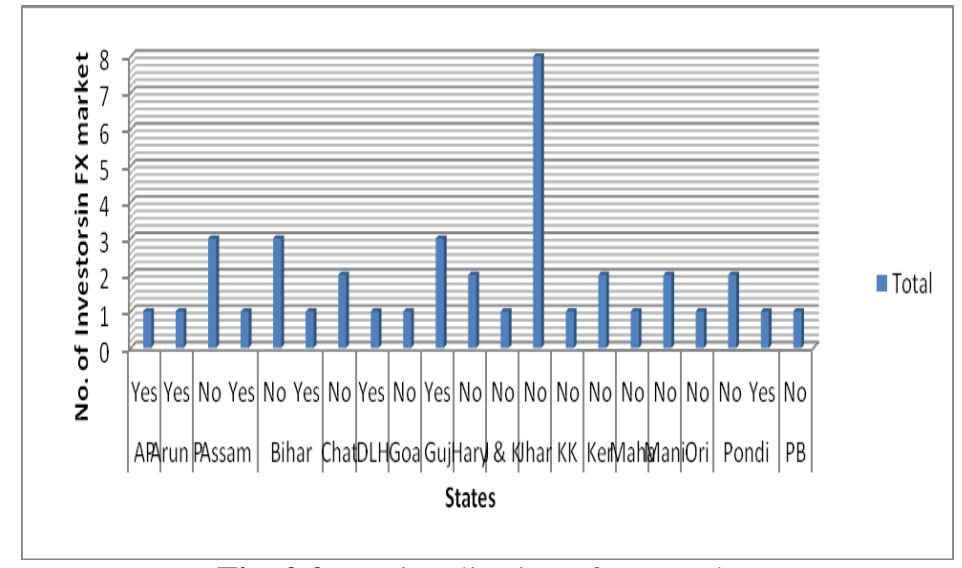

Fig. 2.2 Regionalisation of FX market

\section{Observation about Mineral Industry of Jharkhand}

As earlier discussed, Jharkhand is having a major share of minerals of India which can be seen in the below

graph:-

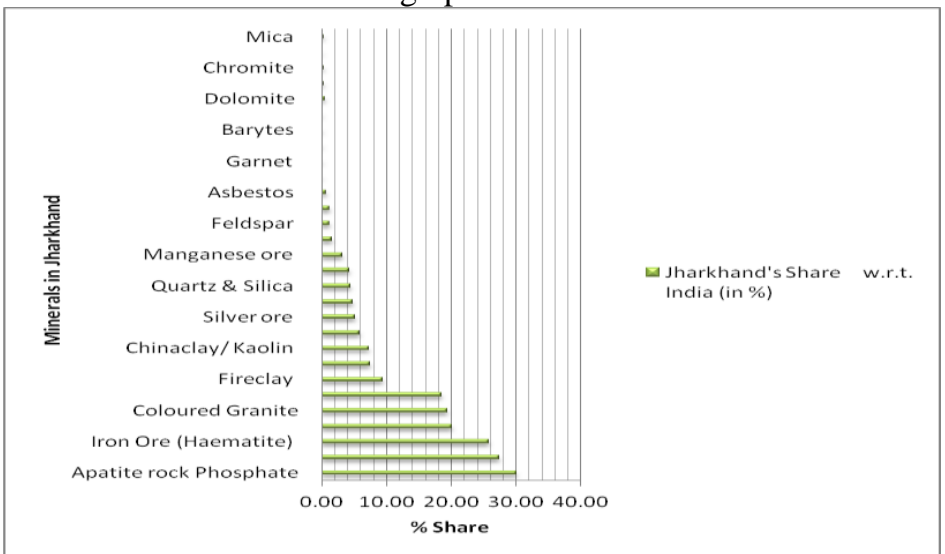

Fig. 2.3 Share of minerals in Jharkhand

The state economy is being supported by its mineral revenue collection which has grown over the years up to around Rs.5,000 cr. in 2015-16 (ref. Fig. 2.4)

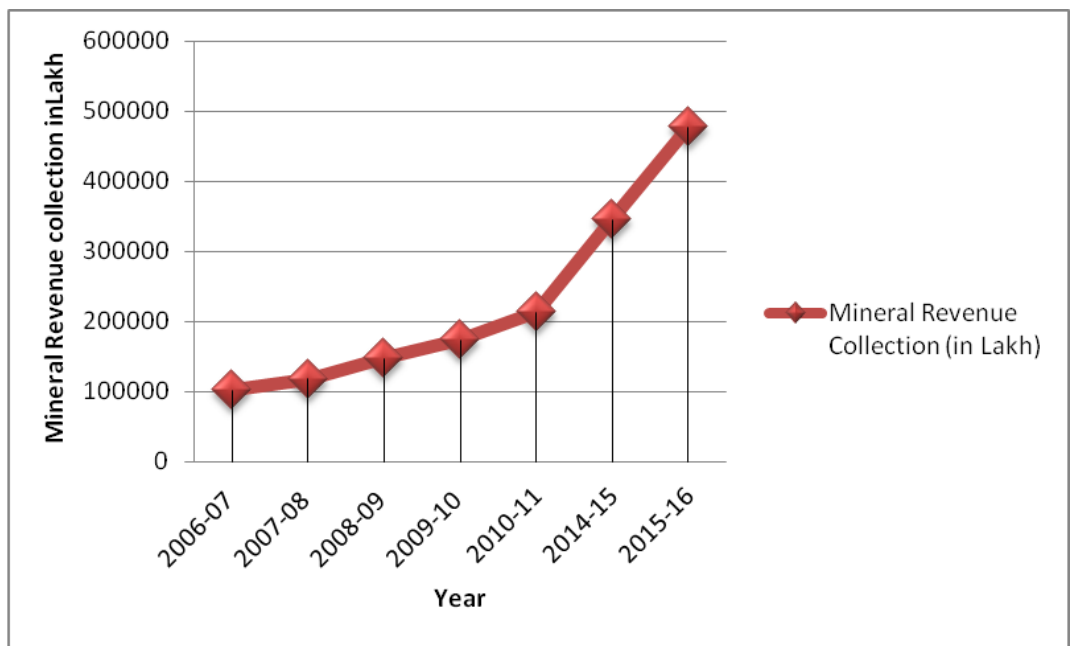

Fig. 2.4 Mineral revenue collection in Jharkhand in last 10 yrs. 


\section{Conclusion}

The environment for the FX market in Mineral belt of Jharkhand state is not so favourable. Business environment is highly differentiated. Technologically, employees are not so competent in some banks/branches and Relationship Managers at some Branches are comparatively lazy. FX product is still an alien concept for small mineral industrialists/ retail traders/investors of Jharkhand.

\section{Recommendations \& Areas for Future Exploration}

RBI's awareness camps about FX should be done more frequently. Commercial Bank's role in FX market must be pro-active. Bank's role is very crucial in passing the information of the availability of cheap loans in foreign countries to customers. Role of FIEO, DGFT \& SLBC should be communicated to exporters of Jharkhand by awareness camps. As Metro cities are becoming cluttered, there are good opportunities in smaller towns and cities in the forex business. An outlet of Thomas Cook in Bihar's Siwan district carries out 600-700 transactions a day, is an eye opener for FOREX traders who are operating in Eastern part of India.

McKinsey \& Company in a report says that by 2020, India may turn from a substantial exporter of Iron ore to just about sufficient to meet its demand and it may need to import up to around 300mtpa of thermal coal and around 40mtpa of metallurgical coal by that time which needs of Forex of about USD 300 billion almost equal to the present total Forex reserve of the country.

Jharkhand is no. 1 producer in Iron ore, Copper ores, Micca, Kainite, Uranium, Asbestos, etc. and having only 19 industries in the state. The state also has cheap labour in its hand. With having two important coordinates of the triangle, Government of Jharkhand should use the Weber's theory of Industrialization. The emerging state of Jharkhand provides the right backdrop for becoming mineral super power which epitomizes phenomenal growth and development symbolizing the best of "Made in India" and "Make in India" and in a similar vein the Indian forex market has also witnessed tremendous growth and development in terms of depth and breadth, particularly since the adoption of market determined exchange rate regime about two decades ago. Although the mining sector has huge potential for growth over the long term, it has high risks that need to be carefully managed. Mining sector need to take key measures like by declaring mining as a strategic sector, state can prevent drain of valuable Forex along with improvements in efficiency and productivity through the use of technology \& skilled mining labour force. By meeting its own demand for mining commodities, India could address its current account deficit substantively. If mining growth continues to be slow, India would incur USD 28 billion forex spend in 2020 and USD 58 billion forex spend in 2025 from iron ore, cocking coal and thermal coal. A balanced strategy would call for broadening the manufacturing base beyond mineral-based industries and establishing forward and backward linkages leading to employment generation. To promote sustained mining development, a strong governance framework and institutional capacity is essential for mitigating social or environmental impact. So this is the right time to replicate South African Model of Forex Earning in Mining Industry to the Mineral Industry of Jharkhand.

\section{Bibliography}

[1]. http://rbidocs.rbi.org.in/rdocs/publicationreport/pdfs/77577.pdf (Section 5.2- Historical Development in Forex Market in India)

[2]. http://www.thehindu.com/business/markets/banks-told-to-enforce-ban-on-card-use-for-online-forex-trade/article5138732.ece retrieved on 18th Oct'14 at 3:46 PM

[3]. Bank for International Settlements, 2005a. Triennial Central Bank Survey: Foreign exchange and derivatives market activity in 2004, Basel, Switzerland

[4]. Bank for International Settlements, 2005b. Foreign exchange market intervention in emerging markets: motives, techniques and implications, BIS Paper No.24, Basel, Switzerland

[5]. Bank for International Settlements. Triennial Central Bank Survey: Foreign exchange and derivatives market activity in 2013, Basel, Switzerland

[6]. Chakrabarti, Rajesh, 2006. The Financial Sector in India: Emerging Issues, Oxford University Press, New Delhi, 2006.

[7]. Ghosh, Soumya Kanti, 2002. RBI Intervention in the Forex Market: Results from a Tobit and Logit Model Using Daily Data, Economic and Political Weekly, June 15, pp.2333-2348.

[8]. Williamson, John, 2006, Why Capital account Convertibility in India is Premature, Economic and Political Weekly, May 13, pp.1848-1850.

[9]. Khundrakpam, J.K. 2007. "Economic Reforms and Exchange Rate Pass-Through to Domestic Prices in India." BIS Working Paper No. 225, February.

[10]. Arora R S (2005).Manual of Foreign Exchange”, Skylark Publication IIBF (2005) “Risk Management”, Taxmann Bose Rupnarayan (2007). "Fundamentals of International Banking", Macmillan Publication

[11]. IIBF (2005). "Practitioner's Book on Trade Finance", Taxmann

[12]. Jeevanandam C. (2008). "Foreign Exchange \& Risk Management", Sultan Chand \& Sons

[13]. Different Clauses related with Foreign Exchange described in Master circulars of RBI, Retrieved on 20 ${ }^{\text {th }}$ April,2012, available in http://rbi.org

\section{Journals}

[14]. Abdalla, I. S. A., and V. Murinde, 1997, "Exchange Rate and Stock Price Interactions in Emerging Financial Markets: Evidence on India, Korea, . Pakistan, and Philippines", Applied Financial Economics, 7,25-35. 
[15]. Abid, F., N. Aoua, and A.D. Mikhail, 2003, "Linkage between, and Contagion in, Asian Stock and Foreign Exchange Markets (September 1987- October 1999)", Finance India, XVII (4), 13 1 1-1343.

[16]. Adler, M., and D. Bamard, 1984, "Exposure to Currency Risk: Definition and Measurement", Financial Management, 4 1-50.

[17]. Agganval, R., 1981, "Exchange Rates and Stock Prices: A Study of U.S. Capital Market under Floating Exchange Rates", Akron Business and Economic Review, 7- 12.

[18]. Ajayi, R.A., and M. Mougoue, 1996, "On the Dynamic Relation betwsen Stock Prices and Exchange Rates", Journal of Financial Research, 19, 193-207.

[19]. Alphonse, P., 2000, "Efficient Price Discovery in Stock Index Cash and Futures Markets", Annales d'Economie et de Statistique, $60,177-188$.

[20]. Amain, B.A., and L.S. Hook, 2000, "The Relationship between Stock Prices and Exchange Rate: Empirical Evidence Based on the KLSE Market", Asian Economic Review, 42 (I), 39-49.

[21]. Antonious, A., I. Garrett, and R. Priestley, 1998, "Calculating the Equity Cost of Capital using the APT: the impact of the ERM, Journal of International Money and Finance, 17,949-965.

[22]. Apte, P.G., 1998, "Currency Exposure and Stock Prices", Journal of Foreign Exchange and International Finance, XI1 (2), 135 - 143.

[23]. Baharumshah, A.Z., A.M.M. Masih, and M. Azali, 2002, "The Stock Market and the Ringgit Exchange Rate: a Note", Japan and the World Economy, 14,471-486.

[24]. Bahmani-Oskooee, M., and A. Sohrabian, 1992, "Stock Prices and the Effective Exchange Rate of the Dollar", Applied Economics, 24, 459- 464.

[25]. Baig, T., and I. Goldfajn, 1999, "Financial Market Contagion in the Asian Crisis", IMF StaflPapers, 46 (2), $167-195$.

[26]. Bailey, W., C.X. Mao, and R. Zhong, 2003, "Exchange Rate Regimes and Stock Return Volatility: Some Evidence from Asia's Silver Era", Journal of Economics and Business, 55,557-584 